\author{
Adrian VELICU \\ independent scholar \\ adrian.velicu01@gmail.com
}

\title{
PARATOPIC RECOLLECTIONS
}

\section{COMMUNISM IN SWEDISH COLLECTIVE MEMORY}

ABSTRACT This paper discusses the collective memory of communism in Sweden after 1989 and its role in the process of Europeanization. Sweden lacks the direct experience of communism and any such recollections are bound to be mediated. Such memories of experiences outside the Swedish political and social context (para-contextual or para-topic instances) are examined in terms of transnational collective memory. That is why the analysis treats these memories as part of the process of Europeanization. The material amounts to institutional and rhetorical examples featuring the memory of communism. Three sets of concepts help scrutinize these sources: Klas-Göran Karlsson's view of three-wave European integration (economic, political and cultural), Avishai Margalit's distinction between 'thick' (family, nation) and 'thin' (humanity) communities of remembrance where the ethics of memory can work transnationally in a context of human rights, and Jeffrey Andrew Barash's connection between 'public memory' and 'imagination'. By discussing the material within this framework, the argument concludes that paratopic recollections and the dynamics of Europeanization converge, highlighting a new aspect in this process of integration.

Key words: memory, communism, Sweden, Europeanization, paratopic

Sweden never experienced communism as a local political system. The general public learned about the concrete phenomenon of communism through media, various accounts provided by groups and individuals visiting Eastern Europe (in one telling case by the return of a group of emigres to Soviet Union), translations, films and the occasional scholarly work that reached a wider readership, to take only some of the main sources. There was in fact a small communist party in Sweden, as well as a number of left-wing organizations of various degrees of militancy. The public stance of the estab- 
lished communist party and the rivalries within the fissiparous left-wing movement offered an ideological perspective which the public could take an interest in or ignore. Lacking the experience of communism, but willing to come to terms with its memory such as it had accumulated in Sweden before 1989, the process of recollection was bound to occur at a transnational level.

The aim of this study therefore is to clarify the nature of the Swedish memories of the crimes of communism as a contribution to the process of Europeanization. An attempt to make sense of this kind of collective memory benefits from placing it in a $\mathrm{Eu}$ ropean context. More specifically, this context is that suggested by Karl-Göran Karlsson, amounting to three successive waves of European integration: economic, political and cultural. ${ }^{1}$ The particular case of Sweden, concerning itself with the manifestations of communism and attempting to integrate it within its collective memory, would belong to the third (cultural) wave of European integration. The circumstances of this sort of recollection amount to an instance of transnational collective memory. Due to the mediated characteristics of this memory, the analysis has to resort to principles and common values that explain the relevance of one community recollecting the mediated experience of other communities, i.e. the Swedes remembering the Eastern-European experience of communism.

These common values have to do with concepts emerging throughout the modern history of Europe: the Renaissance view of the individual as an autonomous being, the Enlightenment outlook on the role of reason and the benefits of education, and the emerging status of citizenship along with the accompanying civic rights. These clusters of values and principles have featured significantly in the formation of a European identity, but subsequently they have not remained exclusively European, spreading beyond its confines. What grants them their defining role as far as Europe is concerned is the particular historical sequence with all the complex intellectual and political ferment which has enabled their rise. These constellation of circumstances included the post-Westphalian beginnings of religious toleration, along with its embryonic idea of observing the sovereignty of the emerging states as well as the increasingly necessary principle of the balance of power. These common values add up to a comprehensive ensemble of principles and concepts. What is particularly important when discussing the memory of communism is the set of values concerning human rights. Articulating the manner in which Sweden shares these basic values when it comes to communism, reconfirms its place in the cultural and political legacy that characterizes Europe.

There has been extensive work on the significance of the memory of the Holocaust for the institutionalization of a European collective memory. ${ }^{2}$ Some of the scholarly work on the memory of communism after 1989 appears to situate it also in this process of institutionalization. The addition of such missing components and therefore

K.-G. Karlsson, "The Uses of History and the Third Wave of Europeanisation”, in M. Pakier, B. Stråth (eds.), A European Memory? Contested Memories and the Politics of Remembrance, New York 2010, p. 38. See also: K.H. Jarausch, "Nightmares or Daydreams? A Postscript on the Europeanisation of Memories", in M. Pakier, B. Stråth (eds.), A European Memory?..., pp. 309-310.

2 K.-G. Karlsson, “The Uses of History...”, p. 295. 
the consolidation of the European collective memory has occasionally been marked by controversy. However, there is a need and a place for a number of potential components of this transnational collective memory that have remained unexplored.

What might appear as the paradoxical case of the memory of communism in Sweden presents a challenge because of its extra-contextual nature (or para-contextual, indeed, para-topic feature, to coin a term). Yet, this challenge can be overcome by the very fact that, in search of a site of memory, it calls for a transnational approach and reinforces its meaning once it is located in a European constellation. It is along these lines that the present study attempts to make sense of the memory of communism in Sweden.

This study distinguishes between the perceptions of communism in Sweden over time, quite often as part of various encounters with the realities of the Soviet Union (but also of Russia before 1917 after 1991), and the mediated memory of communism related to universal principles with an eye to the process of European integration. As far as the Swedish perceptions of communism go, there has been a certain amount of scholarly work. The studies collected in Rysk spegel. Svenska berättelser om Sovjetunionen och om Sverige are representative examples. ${ }^{3}$ The 'memory turn' in some fields within the humanities is yet to be exploited on a wider scale in the specific area of the recollections of communism in Sweden. Some reflections on the significance of this 'turn' in a historical context suggest fertile lines of inquiry. ${ }^{4}$ The present study attempts to make a further contribution in this area.

This discussion proceeds as follows. An introductory section clarifies the theoretical outlook and the methodological approach. A more substantial section presents a number of cases that are particularly significant for the present argument. The analysis identifies those aspects that justify the conceptual outlook of the argument. The discussion concludes with several thoughts on the relevance of these specific cases to European and memory issues.

The process of 'Europeanizing' the memory of communism presupposes the integration of this memory within an explanatory framework based on the political values defining Europe as they have taken shape during and after the Early Modern period. Besides the importance of maintaining the state and of wielding power in relation to the subjects' safety (as argued by Machiavelli and Hobbes), increasingly modern issues as rule by consensus (Locke) and the civic status of the individual in a nation-state (as argued beginning with the French Revolution) have shaped a political landscape containing two elements relevant here: the presence of borders and that of values transcending borders.

3 K. Gerner, K.-G. Karlsson (eds.), Rysk Spegel. Svenska berättelser om Sovjetunionen - och om Sverige, Lund 2008. See also some of the contributions in: H. Blomqvist, L. Ekdahl (eds.), Kommunismen - hot och löfte. Arbetarrörelsen i skuggan av Sovjetunionen 1917-1991, Stockholm 2002 and in: M. Engman (ed.), Väst möter öst. Norden och Ryssland genom historien, Stockholm 1996; also, selected sections on Sweden in: V. Lundell, Det omstridda arvet. Den kommunistiska erfarenheten i dansk och svensk historiekultur, Lund 2017.

4 For example, K.-G. Karlsson, “The Uses of History...”. 
The analysis of any entities that are in the process of being Europeanized entails a discussion in a transnational context. That is why it is profitable to place an investigation of the Swedish memory of communism in a context of transnational collective memory. Scholars have pointed out the need for more work on the various aspects of transnational memory. This brief study of the memory of communism in Sweden intends to add to the range of cases making up transnational memory and hope to clarify one aspect of this phenomenon.

A relevant dimension to the present discussion is Avishai Margalit's concept of the moral witness and his distinction between two types of human relations: thick ones and thin ones. ${ }^{6}$ The former concerns the family and the close community, the latter concerns humanity as a whole. Indeed, Margalit's concept of 'thick' human relations converges with that of transnational/transcultural recollections, outlining even more clearly the kind of context employed here. The lack of the direct experience of communism in Sweden places the recollections of communism as mediated and (partially) integrated in the collective memory within the framework of 'thin' human relations; in other words they are assimilated in Sweden as part of the issues that regard humanity in general. Forcing the issue somewhat, it might be argued that, in a sense, the Swedes can only remember the crimes of communism as Europeans recollecting events that have affected other Europeans.

In a recent discussion of collective memory Jeffrey Andrew Barash explored the connection between 'public memory' and 'imagination.' Aware of the caveats when it comes to accept the concept of 'collective memory' as viable, Barash searched for a justification of using the term 'memory' in the absence of 'encounters in the flesh' with the event itself and finds it in the role played by imagination. His argument draws on the connotation of imagination as used in Benedict Anderson's 'imagined communities' where the process is one of achieving social cohesion. Barash argues further that this recourse to the term imagination permits us to avoid the dilemma that the concept of 'collective memory' would seem to introduce, since imagination as a capacity to maintain and revivify an 'image of communion' on a large scale in no way requires that we invoke the most original feature intrinsic to remembrance of past experience, which is to have encountered what is remembered in the flesh. ${ }^{8}$ Barash admits the risk of blurring the distinction between a social cohesion resting on fantasy (fictional recollections) and one that it may also lay claim to a basis in a 'remembered' past, even where recollection is indirect and bor-

5 A. Erll, Memory in Culture, transl. by S.B. Young, Basingstoke 2011, p. 66; F. Whitling, "Damnatio Memoriae and the Power of Remembrance: Reflections on Memory and History", in M. Pakier, B. Stråth (eds.), A European Memory?..., p. 92; K.H. Jarausch, T. Linderberger, "Contours of a Critical History of Contemporary Europe: A Transnational Agenda”, in iidem (eds.), Conflicted Memories. Europeanizing Contemporary Histories, New York 2011, pp. 1-20; see also: A. Velicu, "The Return of World History and Transcultural Memory”, Buletin Ştiințific. Revistă de Etnografie, Ştiințele Naturii şi Muzeologie (Serie Noua), vol. 21, no. 34 (2014), pp. 74-79.

6 A. Margalit, The Ethics of Memory, Cambridge, Mass. 2003, p. 7.

7 J.A. Barash, Collective Memory and the Historical Past, Chicago 2016, pp. 44-45.

8 Ibid. 
rowed from past experience reported by others. ${ }^{9}$ The concept of 'borrowed memory' has already been used by Halbwachs when he distinguished between autobiographical and historical memory. The term reappears this time under the name of 'indirect recollection'; either way, it constitutes a credible theoretical tool. In so far as the process of Europeanization aims at increasing cohesion of various kinds, the link between memory and imagination acquires a fresh dimension. Consequently, imagination has a necessarily complementary role in the present case, considering the indirect nature of the Swedish memories of communism.

Thus, Karlsson's third wave (cultural) of European integration, Margalit's distinction between thin and thick communities in the context of collective memory and Barash's argument about memory and imagination achieving cohesion establish the theoretical framework of the present discussion. The analysis scrutinizes the empirical cases in the light of these three conceptual tools with the constant reminder that this approach requires a transnational framework in order to prove fruitful when it comes to Sweden.

The subsequent discussion examines a limited but significant number of examples that illustrate the recollection of communism in Sweden. Here follows a concise account of the material used. More details below, as the analysis explores each example in turn.

There is only one case where direct experience of communism, albeit outside Sweden, is involved: the experience recounted in the 1950s and later by the returning survivors and descendants of a group of Swedes who emigrated to Soviet Union in the 1920s and 1930s. The next case, an experiment of a commune based on communist principles in the 1970s offers a further instance of direct experience that has become part of the recollections of communism after 1989. Otherwise, this study has selected examples of recollections of communism after its collapse; these instance occur in several public debates where ideological, ethical, scholarly criteria converge in various constellations. Here the evidence is constituted by rhetorical statements, political declarations or public support expressed towards the communist dictatorships, all these remembered after 1989 in a context of confronting earlier compromising stances with the (European) values that they infringed upon. A case that contains such evidence is the controversy provoked by the decision to include the crimes of communism in an official campaign set up to disseminate information on the Holocaust. Another case that supplies further proof for the present argument concerns the efforts of the Swedish Communist Party to cope and come to terms with its past, as it divested itself of its ideology and of its defining attribute ('communist') after 1989. ${ }^{10}$

\section{Ibid., p. 45 .}

10 The Swedish Democratic Left Party (from 1921 the Communist Party of Sweden, from 1967 the Left Party-Communists, and from 1990 the Left Party) emerged in 1917, after a split within the Swedish Social Democratic Party. Between 1919 and 1943, the Party was a section of the Comintern and, therefore, subordinated to Moscow. The loyalty towards the Soviet Union diminished somewhat after 1956, but Marxism-Leninism remained the Party's ideology until 1990 when it was removed from the charter along with the word 'communist'. The Party, one of the smallest in Sweden, has never been part 


\section{THE KIRUNA AFFAIR}

Several groups of (mainly) communist Swedes emigrated to Soviet Union in the $1920 \mathrm{~s}$ and the 1930s convinced that they would contribute to the creation of a better society. Many came from the northern town of Kiruna and the surrounding area, but quite a few were from other areas in Sweden. Their case became known as that of the 'Kiruna Swedes. Besides, quite a few Scandinavians, including Finns, who had settled in USA and Canada joined them, re-settling in Soviet Union.

Kiruna is a mining town which experienced increased unemployment in the early 1920s. The region has had a tradition of strong left-wing sympathies. The perception of the kind of society that emerged after 1917 in Russia and the propaganda of the Swedish Communist Party determined hundreds of dissatisfied Swedes to emigrate along with their families, most of them in the early 1930s. There were also some immediate incentives: the Kiruna district, which was dominated by communists, subsidized the move and the recruiters (members of the Swedish Communist Party) were paid by the Soviet Legation in Stockholm. ${ }^{11}$ It is not clear to what extent the Swedish Communist Party's contributed, but there seems to have been some more or less informal financial support, apart from help with the formalities. Thus, groups including whole families with small children moved to Soviet Union. ${ }^{12}$

The idea was that they would be settled in the part of the Karelian region that belonged to the Soviet Union. Soon enough, most of them were moved on to far more distant regions, many were arrested and died in prison camps. A very few returned to Sweden with great difficulty. In a series of radio and TV documentaries, books, interviews and other forms of testimonies they recollected their life in the Soviet Union, giving in the process an image of the effects of communism in that country. The present discussion of the 'Kiruna Swedes' proceeds now in two stages: the returned Swedes' memory of communism and the manner their recollections were processed and integrated (or not) in the collective memory of communism in Sweden chiefly after 1989.

Some of emigres who returned in the 1950s actually presented favorable accounts of life in the Soviet Union in radio interviews and, when asked, answered that they might well think of returning. ${ }^{13}$ One of them did admit that things got a bit 'awkward' about 1937 when there was 'more control'. However, other returning Swedes gave a far

of any government coalition, but has been present in the Riksdag (the Swedish Parliament) and has supported at times the Social Democrats. See, for example: P. Bergner, Med historien som motstandare. SKP/VPK/V och det kommunistiska arvet 1956-2006, Stockholm 2013, pp. 7-8 and passim.

11 K. Eneberg, Förnekelsens barn. Svenskarna som drog österut, Stockholm 2003, pp. 24-25. According to archive documents, some recruiters were paid 100 Swedish kronor per worker who emigrated, approximately 600-1,000 euros in today's money.

12 “Kirunasvenskarna”, Forum för Levande Historia, 2013, at <http://www.levandehistoria.se/faktafordjupning/kommunistiska-regimers-brott-mot-manskligheten/kirunasvenskarna $>, 10$ February 2017; K. Eneberg, Tvingade till tystnad. En okänd historia om några svenska familjeöden, Stockholm 2000, pp. 24-25.

13 “Kirunasvenskarna - drömmen om Stalins Sovjet", Sveriges Radio, 3 May 2015, at <http://sverigesradio. se/sida/avsnitt/537025? programid=2519>, 11 February 2017. 
less flattering picture. They talked about arrests, deportations to Siberia, trials and sentences based on imaginary accusations of espionage and, on the whole, general poverty and a dysfunctional economy. These people were harshly criticized and occasionally bullied by local members of the Swedish Communist Party, while being ridiculed in its newspaper Norrskensflamman. At least one emigre returned as late as 1991, as the Soviet Union was about to collapse. All in all, through such public recollections and accounts, the general public learned more and more of these Swedes' life and suffering under the Soviet regime. These recollections can be summed up by one of the women interviewed for the radio documentary mentioned above: she was haunted by the horrible memory of the Soviet terror. ${ }^{14}$ Her father had been arrested and was never heard of again (according to subsequent archive research, he was executed), at the age of eighteen she was summarily tried by an improvised court of three officers and sentenced to ten years in prison for spreading anti-Soviet propaganda when she was seven years-old. A further accusation was that of espionage. ${ }^{15}$

When Kaa Eneberg, a retired journalist from the main Swedish daily Dagens Nyheter, started to research the story, including visiting the recently (and in some case temporarily) accessible archives of the former KGB/NKVD/OGPU, she found evidence of $S$ wedish emigres being arrested, imprisoned on trumped up charges, or executed. The individual memories of the returned emigres and their general status became the subject of wider debates. The Swedish (formerly Communist) Left Party had to deal with this issue, this time publicly, while being confronted by an avalanche of new information originating in the former Soviet Union. The question of an apology owed by the Party to the surviving 'Kiruna Swedes' gradually emerged and a letter of apology to their relatives was drafted. It was supposed to be signed by the Party leader at the time (2000), Gudrun Schyman, and by two previous Party leaders. The text circulated for a while and it appeared that the Party Secretary (and later leader, Lars Ohly) had cut out the word 'apology' and he had also edited out references to the communist terror. The cuts were in response to the protests of the northern Party district (comprising Kiruna) who wanted to know why the Party should apologize at all. That letter was never sent, but four years later, an investigative TV documentary into the past of the Communist Party in Sweden interviewed Ohly on the Kiruna issue. The politician got entangled in contradictory explanations, claiming that the cuts in the letter were agreed on collectively. On the whole, although faced with the reporter's evidence, Ohly denied that the Party and he himself had supported the communist dictatorships before 1989. The subsequent TV debate and the national Swedish press brought the subject to the attention of the general public. Eventually (2004), Ohly did apologize to the relatives of the emigres for the way the Party treated the survivors on their return from the Soviet Union.

Further evidence of how delicate this issue has been can be found in the repeated attempts of the Liberal member of the Swedish Riksdag (Parliament) Gunnar Andrén

14 Ibid.

15 Ibid. 
to move a resolution concerning the case of the 'Kiruna Swedes'. As late as 2013 he reminded his colleagues in his bill that it was the ninth time he tried to have a parliamentary debate and decision on this subject without any success. The resolution was dismissed once more, although previously the Minister of Culture had admitted in principle that the subject merited closer examination.

After the toing and froing regarding the apology of the Left (formerly Communist) Party to the survivors among the 'Kiruna Swedes', in 2015 the Party tried to make amends by suggesting in parliament the raising of a memorial to the members of this group. ${ }^{16}$ The authors of the proposal argued that disseminating knowledge about political terror would enable us to draw a lesson for the future. Further, honoring these people for the suffering under the 'Stalinist terror' is a matter for the entire nation, not just one party. The word 'terror' recurs throughout this brief proposal and its recollection through a memorial is regarded as a lesson. It is not clear what kind of lesson the recollection of the Soviet terror would imply for a country that never experienced communism and this is not the place for scrutinizing the thought behind the proposal. One can only suggest a line of enquiry on the phrasing in this proposal and elsewhere that learning the lesson by imagining the terror is the kind of mechanism that helps to create an indirect memory, lacking direct experience. It should be noted that the Parliament dismissed the proposal the following year, referring to the work already being done by the Living History Forum (more on the Forum in a subsequent section below).

Irrespective of the proper legal course to be followed, it is significant that Leo Eriksson, the son of one of the returned women from Soviet Union and the person who became a spokesman for the surviving emigres, turned to the Swedish Communist Party for an apology. His recorded discussion with two of the party leaders witnessed by the journalist Kaa Eneberg where Leo Eriksson presented his claim, the hesitation of the leadership concerning an official apology, the subterfuges, the delayed apology, as well as the debate show how delicate the matter was for the Swedish (former) communists, but also for legislators.

In the case of the people returning from Soviet Union and recounting their experiences, memory works without needing the contribution of the imagination. Without a comprehensive inventory of the Swedes' direct exposure to the communist system it can only be argued here that these emigres' memory of communism is the only instance where imagination, as discussed by Barash, need not enter in the process of shaping collective memory. As they place their recollections in the public domain, these accounts may be shared by the general public or not. It is at this subsequent stage that imagination is required in order to integrate these recollections in the collective memory. In addition, the range of reactions to the emigres' accounts shows the extent to which their fellow-countrymen at home are willing to share and internalize these memories, thus joining the 'thin community' structured by values and human concerns, in the sense used by Margalit.

16 Motion till riksdagen 2015/16:101 av Mia Sydow Mölleby m.fl. (V). Minnesmärke för Kirunasvenskarna, at <https://data.riksdagen.se/fil/4D125B74-6D00-481A-ACAD-2B3C1894DE50>, 12 February 2017. 
As for sharing these memories, the reactions of those close to the emigres, as summed up above, speak for themselves. At the time of the return, the local community was hostile, while the Communist Party, through its newspaper and some of its members, was downright aggressive. This is evidence indicating that those socially and politically closest to the emigres were reluctant to integrate the recollections of communism within the local collective memory. After 1989, the general public re-discovered the episode through newspaper articles, TV and radio documentaries and the debates on the apology that the (former) Communist Party may or may not owe to the emigres. The events of 1989 and, in the emigres' case more emphatically, the collapse of Soviet Union in 1991, vindicated the emigres' accounts. The politicians and other individuals more or less directly involved in this case tended to place their post-1989 recollections in a rather self-righteous context, trying to distance themselves from the pre-1989 reactions.

\section{A MAOIST INTERLUDE}

A brief but intense experiment undertaken by one of the Swedish extreme left-wings parties in the early 1970s has become publicly known after 1989 and has entered the collective memory of communism. In 1967 a small Maoist group in the Swedish Communist Party split from the organization and set up its own political outfit called KFML (the Communist Marxist-Leninist League). A further split occurred early in 1968 when an even tinier group who called themselves 'The Rebels' and occasionally 'The Double Maoists' established their own organization.

Such splits echoed the ideological tension between Soviet Union and China that had been gradually intensifying throughout the 1960s. The political background was also altered by the fact that the Soviet system was losing some of its appeal after Khrushchev's speech of 1956 where he criticized Stalin, after the invasion in Hungary in the same year and after the invasion in Czechoslovakia in 1968. In the late 1960s, Solzhenitsyn's works became widely known in the West, adding to the dissatisfaction of some members of left-wing circles with the Soviet Union. They started to look further afield, towards China and the Maoist model, for inspiration. ${ }^{17}$ Significantly, on-going disputes characterized the Swedish Communist Party as well: the adepts of the ideological mainstream, the new Leninist and the 'old communists' featured repeatedly in the internal arguments of the Party between 1967 and $1977 . .^{18}$

A radio documentary called 'The Rebels' broadcast in 1997 and again in 2009 explored the memory of the miniscule group of Maoists mentioned above who started

J. Stenfeldt, Dystopiernas seger. Totalitarism som orienteringspunkt i efterkrigstidens svenska idédebatt, [Höör] 2013, pp. 173-191.

18 See: L. Berntson, S. Nordin, Efter revolutionen. Vänstern i svensk kulturdebatt sedan 1968, Stockholm 2017 , p. 21. 
their underground communist organization. ${ }^{19}$ Its members lived in communes mainly in the Stockholm area and were organized in cells that did not know of each other's whereabouts and doings. A strictly hierarchical leadership with a central committee and one leader at the top controlled all activities and information. Children were taken away from their parents to be brought up separately at addresses unknown to their parents. Ideologically 'suspect' books, records and other materials were destroyed, an ascetic life style was cultivated and sustained political instruction went on, including energetic self- and mutual criticism accompanied by psychological and, allegedly, physical pressure. The experiment lasted for a few months. The movement split yet again and most members left the faction.

In this documentary, as well as other radio programs, ${ }^{20}$ former members of the movement remember their ideals and actions about 30 years later as historians, along with other observers, attempt to make sense of these recollections. As practically the only known instance of what might be called applied communism in Sweden, however severely confined in time and space, the case of the short-lived Maoist commune has been registered by the Swedish collective memory in a peculiar way. This brief experiment appears to have been recollected as an odd episode, regarded as an extravagant escapade rather than as a sinister warning. Its extreme nature deprived it of realism for the ordinary citizen who may have missed the worrying dimensions of this practice of the theory and theory in practice. Therefore, the way to retain it in the public memory is by considering it a manifestation of a specific, extreme left-wing, tiny political party (KFML), rather than an expression of the applied ideology of communism.

The Kiruna affair and the Maoist experiment constitute two examples where the memory of communism is based on palpable experiences. They may appear rather insignificant in view of the recent history of Central and Eastern-European countries scarred by five or more decades of communist dictatorship. Nevertheless, these examples acquire a particular intensity in a country like Sweden which was spared the direct experience of communism. The present discussion proceeds now by recounting and analyzing a different type of example. These examples deal with recollections to mediated images of communism, filtered through rhetoric, ideology and political tactics, all this projected against a background of European integration.

\section{THE LIVING HISTORY FORUM}

A controversy that is particularly significant for the memory of communism in Sweden was provoked by the decision of the Living History Forum (Forum för Levande Historia) to extend its initial information campaign on the Holocaust to disseminating

19 "Rebellerna”, Sveriges Radio, 28 June 2009, at <http://sverigesradio.se/sida/artikel.aspx?programid= 909\&artikel=2895155>, 29 January 2017.

20 See, for instance: "Om bokstavsvänstern", Sveriges Radio, 24 September 2015, at <http://sverigesradio. se/sida/avsnitt/620692? programid=4747>, 30 January 2017. 
information on the crimes of communism as well. The background to the setting up of the Forum was the ignorance of school students about the Holocaust revealed by opinion polls and scholarly work in 1997. The Swedish Prime Minister at the time, Göran Persson, initiated at first an information campaign called Living History which was to be coordinated and steered by established scholars.

In 2003 this activity was allocated resources and staff on a permanent basis and was thus consolidated as a state institution. Its purpose has been that with the starting point in the Holocaust, to promote democracy, tolerance and the equal worth of all human beings. ${ }^{21}$ After the general election in the autumn of 2006, the Social-Democrat government was replaced by an alliance of center and right-of-center parties. The new government asked the Forum to include in its information the crimes of communism in addition to those of the Holocaust. The focus would be on Soviet Union, China and Cambodia during 1917-1989. Consequently, the rephrased aim of the Forum has been to inform about the Holocaust and about the crimes against humanity of the communist regimes. 22

The timing of expanding the remit of the Forum may have been due to several factors. It could be argued that the new non-socialist government was more readily disposed to throw light on the crimes of communism. It should also be pointed out that as early as January 2006, the Council of Europe published a resolution condemning crimes of totalitarian communist regimes. ${ }^{23}$ International scholarship such as the collection of studies Stalinism and Nazism. Dictatorships in Comparison was also drawing attention to the parallelism between the Holocaust and the crimes of communism. ${ }^{24}$

The rapporteur in the case of the Council of Europe's resolution was the Swedish politician Göran Lindblad (the Group of the European People's Party). The earlier Report to the Political Affairs Committee (16 December 2005) that led to the Resolution included the recommendation to launch a public awareness campaign on the crimes committed by totalitarian communist regimes at European level. ${ }^{25}$ It is worth dwelling on the distinction made in the report between ideology and practice, since it is particularly relevant for the subject of the present discussion. The author of the report states that Personally, I do not share the position of some colleagues that a clear distinction should be made between ideology and practice. The latter drives [sic; misprint for 'derives'] from the former and sooner or later the initial good intentions are overtaken by the totalitarian one

21 “Om oss", Forum för Levande Historia, at <http://www.levandehistoria.se/om-oss>, 17 January 2017.

22 Ibid.

23 "Resolution 1481 (2006): Need for international condemnation of crimes of totalitarian communist regimes", Parliamentary Assembly of the Council of Europe, 25 January 2006, at <http://assembly.coe. int/nw/xml/XRef/Xref-XML2HTML-en.asp?fileid=17403\&lang=en>, 15 February 2017.

24 I. Kershaw, M. Lewin (eds.), Stalinism and Nazism. Dictatorships in Comparison, Cambridge 1997.

25 "Doc. 10765: Need for international condemnation of crimes of totalitarian communist regimes", Parliamentary Assembly, 16 December 2005, at <http://assembly.coe.int/nw/xml/XRef/X2H-Xref-View HTML.asp?FileID=11097\&lang=EN>, 15 February 2017. 
party system and its abuses. ${ }^{26}$ In the subsequent Resolution Need for international condemnation of crimes of totalitarian communist regimes published about a month later, the rapporteur's opinion appears to have prevailed over the position of some colleagues. The Resolution specifies that The crimes were justified in the name of the class struggle theory and the principle of dictatorship of the proletariat. The interpretation of both principles legitimised the 'elimination' of people who were considered harmful to the construction of a new society and, as such, enemies of the totalitarian communist regimes. ${ }^{27}$ Thus, some of the chief principles of Marxism are to be condemned as part and parcel of the political system that collapsed in 1989/1991. The nature of the condemnation urged by the Resolution suggests that ideology and practice were entangled in a web where the mutually corrosive naïve utopianism, semi-literate dogmatism, self-righteous justifications and ruthless exercise of power annihilated one another along with vast number of people.

The official decision that information on the crimes of communism should be included in the activity of the Forum touched a raw nerve. The reaction amounted to protests, controversies and criticism of an intensity unknown during the initial campaign on information about the Holocaust. ${ }^{28}$ An appeal signed initially by over 250 scholars (mainly historians) protested against the government's 'ideological aspects' in its information campaigns. Although the protesters wrote that they were of various political persuasions, their number included a considerable number of publicly committed left-wing persons (on the website set up for the purpose, the number of signatories eventually reached 466 by 22 October 2010). ${ }^{29}$ The reactions to this appeal can be summed up by the intervention of the political scientist Bo Rothstein who pointed out the lack of consistency in the attitude of the signatories: they protested against a nonsocialist government's initiative when it comes to communism, but they were silent when the Social-Democrat government behaved similarly when it financed and, hence, steered work on other specific subjects and fields. ${ }^{30}$

The chief comments in the main press were mostly favorable to the Forum's extended activity to include disseminating information on the crimes of communism. An editorial in the Swedish daily with the widest circulation, Dagens Nyheter, wrote that there were good reasons to draw attention to the communist wholesale murder and genocide. ${ }^{31}$ Yet, the editorial distinguished between the need to investigate the crimes of communism and whether it is proper for a state authority to act as an opinion maker. The newly appointed superintendent of the Forum, the theologian Eskil Frank, declared

26 Ibid.

27 Ibid.

28 On the different standards and outlooks in Sweden regarding Nazism and communism, see: U. Zander, Fornstora dagar, moderna tider. Bruk av och debatter om svensk bistoria frain sekelskifte till sekelskifte, Lund 2001, pp. 448-450.

29 “Upprop mot statlig kampanjhistoria”, Lista över samtliga undertecknare, at <http://www. historieuppropet.se>, 11 February 2017. See also: J. Stenfeldt, Dystopiernas seger..., pp. 265-271.

30 B. Rothstein, "Forskaruppropet i DN saknar konsekvens", Svenska Dagbladet, 5 April 2008.

31 Dagens Nyheter, 23 December 2006. 
that investigating the crimes of communism was just as important as investigating Nazi crimes and it may contribute to stopping these crimes from happening again. ${ }^{32}$ An editorial in the Swedish daily Svenska Dagbladet introduced a distinction worth pursuing in another study. The daily was somewhat skeptical about the Forum's insistence on regarding their assignment as dealing with crimes against bumanity during communist regimes and not with the crimes of communism against humanity as the government rephrased the initial assignment in $2007 .^{33}$

This brief account of one example concerning the memory of communism in Sweden has confined itself to a few selected interventions in the media. In this absence of an exhaustive scholarly survey, it is at this level that one may try to gauge the presence of particular collective recollections and to identify attempts to revive them or, indeed, suppress them. The inconsistency of the signatories of the appeal is plain to see. What is more elusive in this case is the set of reasons that fuel the commitment of the protesters. They restated the argument in terms of general policy. Further, they argued that the authorities should have no say in the orientation or diffusion of this information. Next, they reminded the public that the value-free teaching and dissemination of history along with the credibility of scholars must be preserved. On the whole, hardly any genuine intellectual would object to this line of thought.

However, given the public image of quite a few of the protesters in the Swedish context, there is more than a touch of special pleading here. The sudden worry about (uncomfortable) 'ideological aspects' can hardly conceal the ideological sensitivity when it comes to examining the crimes of communism in a country lacking its direct impact; such an examination would include a scrutiny of a number of the signatories' ideologically-driven work and public stance. According to a recognizable pattern that resorts to deflecting methods, the signatories of the appeal responded to the initiative on the crimes of communism by referring to the need for examining the crimes of colonialism and the inequality existing in the capitalism system. The protesters refused to engage with the specific claims that the Forum adduces about communism, but reacted in general terms on matters of principle or widened the discussion as a way of avoiding a precise answer on a specific issue. In fact, the protesters' stance took its place among the various mechanisms of forgetting. Given the para-contextual nature of recollection in this case, namely the 'borrowed memories' of events located elsewhere, the appeal of the 466 amounts to avoiding a form of transnational memory sharing that would otherwise reinforce a common European background.

How representative are the 466 signatories of the general public? For the sake of balance, one should mention that among them there are people from at least one liberal think-tank (Timbro) known for its objections to state intervention and who most likely signed on these grounds. As far as a certain category of left-leaning academic intellectuals are concerned, they seem to present a reasonable reflection of the academic world; less so, of the wider world. This case supplies however a regional correction to

32 E. Frank, "Nu granskar vi kommunismen", Svenska Dagbladet, 2 September 2007.

33 “Kommunismens brott mot mänskligheten”, Svenska Dagbladet, 11 March 2008. 
Tony Judt's statement that With the post-Communist re-ordering of memory in eastern Europe, the taboo on comparing Communism with Nazism began to crumble. ${ }^{34} \mathrm{Judt}$ 's otherwise penetrating insights and valuable scholarly work offer a useful background to post-89 Europe against which to contemplate the Swedish case discussed here. While Judt is of the opinion that politicians and scholars started to insist upon such comparisons $^{35} 20$ years after the collapse of communism, here we witness the case of hundreds of Swedish scholars (and some politicians) who campaign a ga inst such comparisons. The rather steady and smooth process assumed by Judt's observations seems therefore to be more problematic in Sweden. Various categories of intellectuals appear to be out of step with each other, judging by the lack of consensus on the Forum's initiative treating Nazism and communism in the same manner.

Swedes can only recollect the practice of communism located elsewhere, as mentioned above; yet, they can recollect the constellation of debates, appeals and various arguments ranging from crude to cultivated ones, invoking the ideology of class struggle and of the dictatorship of the proletariat. These undercurrents of memory drag along quite a few individuals whose intellectual investment in, and political commitment for, principles such as class struggle and dictatorship of the proletariat impels them to try and rescue the ideology.

The European Parliament announced the European Day of Remembrance for Victims of Stalinism and Nazism in 2008, as a result of the Prague Declaration on European Conscience and Communism. Pursuing the same idea, along with similar initiatives, the European Parliament proposed in the following year the creation of a "Platform of European Memory and Conscience" which became an educational project in 2011. At about the same time, an all-party group of members of the European Parliament took the initiative of launching the Reconciliation of European Histories Group, an informal group which co-operates with the "Platform of European Memory" project. As the Living History Forum has included in its activity the dissemination of information on the crimes of communism, despite the appeal of 466 and other objectors, it may be argued that Swedish collective memory on this issue has been in tune with the European outlook.

\section{THE HAUNTING CONSONANT}

The post-1989 initiative of the Swedish Communist Party to render a public account of certain aspects of its past is quite instructive. At its congress in 1990 the Party decided to commission a report of its former relations with other communist parties, including the East European ones. In 1991 the Executive Committee selected a group of

\footnotetext{
34 T. Judt, Postwar. A History of Europe since 1945, London 2007, p. 826.

35

Ibid.
} 
individuals to draft this report and the text appeared in $1992 .{ }^{36}$ The foreword provided a few background details to justify the sketchiness of the report: one author abandoned the project, another one was drafted at short notice and a third one (the historian of ideas Sven-Eric Liedman) explained in his contribution that initially he declined the invitation because of lack of time and due to his own similar work in progress; however, since he was allowed to contribute on his own terms, he assumed that he may offer a few brief personal reflections on the 'guilt' of the Party. ${ }^{37}$ Under these circumstances, the authors amounted to two historians and a political scientist, all three 'independent' scholars but 'close' to the Party, as the authors put it in the foreword. A local politician contributed a text as well.

The result was a slim 'report' made up of uneven contributions. The book was discussed publicly at the Party's congress of 1993. The limited time framework, the rather hurried process of recruiting the authors and the narrowly focused aim of the work give pause for thought. This was supposed to be an undertaking where, after the collapse of communism in Eastern Europe and the Soviet Union, a Western Communist Party invites established scholars to survey decades of the Party's activity. It was an opportunity to come to terms with a range of grave and delicate issues, as one's ideological adversaries relentlessly pointed out that their opposition has been vindicated: communism has imploded in peacetime. Yet, the enterprise appears hastily cobbled together to get the matter out of the way. The report on the narrow issue of the Party's relations with communist parties in Eastern Europe (but also elsewhere) commissioned immediately after the collapse of communism signaled in what field the Party considered that it ought to make amends. This was also an indirect indication that no other sphere of activity of the Party was in need of scrutiny.

The similar haste to drop the letter ' $k$ ', and the word 'kommunist' from the name of the Party (Vänsterpartiet Kommunisterna, abbreviated as VPK) bears the same mark. As a further attempt to come to terms with the past, this particular initiative indicates a wish to forget rather than to confront one's earlier actions and (allegedly) former ideology. I return below to the fate of the word 'communist' in the Swedish Communist Party's name, as an attribute to be accepted, discarded, accepted again and then once more discarded by members of its leadership and other adepts.

The report appears to have made a stir mainly in left-wing publications. On the whole, the report covers institutional and ideological matters which the Swedish Communist Party deemed that required examination after the collapse of communism. The authors confine themselves to surveying institutional contacts with communist parties abroad and exchanges of congratulatory messages (with the exception of Sven-Eric Liedman's few pages which do come close to the heart of the matter but don't expand the argument beyond a few personal reflections). There is little if any comment on the

36 “Uppdrag och uppläggning”, in L.-A. Norborg, S.-E. Liedman, U. Nymark, Lik i garderoben? En rapport om SKP/VPks internationella forbindelser, Stockholm 1992, p. 3.

37 Ibid., pp. 3-4. Also: S.-E. Liedman, “Ovetenskaplig efterskrift”, in L.-A. Norborg, S.-E. Liedman, U. Nymark, Lik i garderoben?..., p. 105. 
way the party has been perceived in Sweden over the decades or on the Party's interventions on the few occasions when it was put to the test, as in the case of the return from Soviet Union of the disappointed emigres. Significant enough for the subject of this paper is the response to the publication of the Swedish translation of Stephen Courtois's The Black Book of Communism. According to the writer and journalist Per Landin, the book provoked an 'outcry' in several European countries, but this was not the case in Sweden. ${ }^{38}$

In 1990 the Swedish Communist Party dropped the word 'communist', and thus the initial ' $\mathrm{k}$ ' from its abbreviated name, being known thenceforward as the Left (Wing) Party (Vänsterpartiet, now abbreviated as V). This attempt to draw a veil over the ideological past only stimulated recollections of the party's earlier politics. Gone was the letter that stood for what now the party considered a compromising past; yet, the absent initial became the haunting initial. The media and the public at large kept returning to the decision of the party, perpetuating thus the memory of its communist past. Newspapers along with television and radio programs gave voice to a wide range of people criticizing the party for opportunistically trying to shake off a dubious ideological past or for just undertaking a cosmetic change. ${ }^{39}$ These debates occasioned a review of the crimes of communism in Central and Eastern Europe, accompanied by rather specious distinctions from the Left between the still intact ideal and the flawed practice. The party's active effort to forget uncomfortable chunks of its past by modifying its name and trimming its ideology simply drew even more attention to what was there to be remembered. And those who knew little of this past became curious to find out what was there to be reviewed and reconsidered.

It is difficult to assess whether renouncing the key word in the name of the Party was a way of performing mea culpa or not, but the brief and selective commissioned report and the Party's reactions to it conveyed the point that, on the whole, there was nothing to be guilty about. Strictly speaking this was true: there was no specific wrongdoing in practice since the Party never had power in Sweden. What remained to be examined was the ideology which, as seen in the European resolution above, goes hand in hand with (potential) practice and should be judged accordingly.

The Party acquired a new leader early in 1993, Gudrun Schyman. The word which had been dropped from the name of the party was still fresh in the memory of the radio reporter who asked Schyman in an interview whether she had ever been a communist. She denied..$^{40}$ The reporter reminded Schyman of her membership in the Marxist-Leninist Militant Association in the 1970s (Ob, you go that far back in history, she laughingly realized), and of the political program of the Association which included 'armed struggle' against the political system. Schyman admitted her membership but

38 Dagens Nyheter, 20 January 2000. See also: J. Stenfeldt, Dystopiernas seger..., pp. 278-281, and L. Berntson, S. Nordin, Efter revolutionen..., pp. 205-214. 
dismissed any suggestion that she was a communist or that she joined the organization on ideological grounds (there were other reasons [...] [laughter]). ${ }^{41}$ In this particular case, the reporter confronted the party leader with the recollection of the violent aims of the Association's political program: 'armed struggle,' 'armed revolution', 'the working class should be armed.' The reactions of the radio listeners to this and similar interviews merit a separate study; suffice it to be said here that the element of violence dismissed in this interview by means of a few flippant remarks was not a purely theoretical supposition, but it set up resonances of the real violence in Eastern Europe at the time brought to the knowledge of the Swedish public by the media after 1945. The nature of this interview may well require a clarification. Needless to say, one should distinguish between Schyman's levity as such and its status as evidence for the present argument.

Things became even more confusing when a subsequent leader of the Party (Lars Ohly) kept changing his mind about his own political allegiance, one moment announcing that he was a communist, then that he was not. ${ }^{42}$ When Ohly claimed in 2004 that he actually was a communist, questions accumulated: what did this return to the fraught term mean, why was the word removed from the party's name and from its program in 1990, and indeed what did it mean prior to 1989 . A couple of party members asked Ohly to stop calling himself a communist since the party must show that it is on the side of democracy. ${ }^{43}$ The party leader stuck to his guns, for a while. However, it appeared that Lars Ohly never ceased to reflect on the matter. In October 2005, he explained that, after all, he would stop calling himself a communist since the term is associated with oppression. ${ }^{44} \mathrm{He}$ further elaborated that this change was necessary because the word 'communist' hindered proper political discussions on topical issues.

The first decade of the $21^{\text {st }}$ century witnessed a number of television documentaries that investigated the past of the Swedish Communist Party. Lars Ohly, was one of the protagonists in these programs, partly because of his position but also as an individual whose shifting outlook aroused particular interest in his real attitude. On one level there has been his changing attitude about his own political identity; apart from the vacillations mentioned above, he denied in 2010 that he was a Leninist only for the reporter to remind him that he did say he was a Leninist in an interview granted to British publication as late as 1999. On another level there has been the extent to which he mirrors the Communist Party's stance whose standpoints (past and present) he had to account for as its leader. The media's interest in the matter was accompanied by Party members' criticism, but also support of their leader and of the Party's actions in general. These have been periodical reminders of the trajectory of communism in Sweden prior to 1989 and the fitful attempts of coming to terms with the past after 1989. In so far as

41 Ibid.

42 For a retrospective of these claims, see: Lars Oblys mörka forflutna, Sveriges Television, 16 August 2009, at <https://www.youtube.com/watch?v=RbzRZWFZHs4>, 31 January 2017.

43 “Tungt vänsteravhopp i protest mot Ohly", Sveriges Radio, 14 October 2004, at <http://sverigesradio. se/sida/artikel.aspx ?programid=83\&artikel=486827>, 31 January 2017.

44 "Lars Ohly slutar kalla sig kommunist", Sveriges Radio, 30 October 2005, at <http://sverigesradio.se/ sida/artikel.aspx ?programid=83\&artikel=723787>, 1 February 2017. 
the general public has taken an interest in this subject, the collective memory of communism is still in the process of taking a recognizable outline, but decisive evidence is difficult to come by.

The hurried initiatives undertaken by the Party could only stimulate similar initiatives coming from other quarters such as media, the academic world, certain political circles and popular writers. If the Party itself wanted to readjust its image by erasing (indeed, forgetting) uncomfortable terms and arguments, others wanted to examine this image by reviving the past. One ought to make a distinction between the popular and the academic contributions to the memory of communism in Sweden. These two kinds of contributions occur in different contexts. There has been a popular one that has tended to approach the subject in terms of the role and actions of communist organizations in Swedish politics. Then there has been an academic one characterized by historical scholarship as well as theoretical perspectives (e.g. genetic or structural perspectives) and concepts (e.g. intention or function as decisive factors), in comparisons between communism and fascism/Nazism. These different sorts of contributions may concisely be illustrated by the survey of the Swedish Radio's correspondent in East Europe Kjell Albin Abrahamsson on the one hand and by scholars mentioned above such as Karl-Göran Karlsson. ${ }^{45}$ In their own particular manner, such accounts work at various levels in the overall perception of communism in Sweden and are available to be retrieved from the collective memory, depending on the kind of (mediated) recollection needed in national or transnational arguments.

\section{CONCLUDING REMARKS}

The ontological status of the features that define Europe has varied over the years. These features and values have manifested themselves at some point in history in certain areas, but not at other moments when they were suppressed or were assumed to have, or did have, a latent existence. For practical purposes, in such cases these defining features are absent. This eclipse of characteristic values occurs during periods such as the communist rule. Once these values re-emerge, or the context allowing their existence re-appears, it becomes possible to contrast their renewed presence with their temporary absence. In other words, it becomes possible to recollect the communist period as a break in the process of shaping and upholding the characteristic European traits. The nature of this recollection, whether condemnatory, critical or otherwise, places the collective memory of communism in a context of recognition of those areas that underwent the ordeal as, once more, part of Europe. I suggest that this is one way in which the dynamics of the process assumed by the term 'Europeanization' and the dynamics of the process of collective memory can be brought together and explain one another. The etymological connotations of 're-cognition' play their additional part in this process.

45 K.A. Abrahamsson, Lät migfå städa klart! Om kommunister, kryptokommunister och antikommunister, Stockholm 2015. 
The use of the term 'totalitarian' in the European documents mentioned above points to the justification of tackling the issue of the crimes of communism in the same manner one has tackled the Holocaust. At times and in certain places, as seen above, the condemnation of the latter has been less controversial than that of the former. The Nazi ideology's dire consequences for universal values can already be seen in its theoretical premises, such as they are. In the case of communism, commendable Enlightenment values (emancipation, rationality) have been emphasized but woven together with later concepts, occasionally toned down, such as class struggle (with its ominous implications): a diffuse alternation between theory and practice that tended to cloud the issue and obscure the flaws. However, as empirically established when implemented, the communist ideology's outcome turns out to be nefarious in similar ways to that of Nazism, except for the former's sinuous trajectory from its imposition to its collapse in $1989 / 1991$.

The analytical demands of a concept such as 'totalitarianism' (categorization, comparison) invite a close scrutiny of the crimes of communism on the same empirical premises as the examination of the Holocaust. Such a comparative undertaking reveals occasionally a lop-sided approach that has to be redressed, as was the case with the latter campaign of the Living History Forum. An outlook that has totalitarianism as its defining feature should help the sheltered observer to detach the reality of dictatorships from the would-be redeeming components of ideology.

Given the unusual circumstances of the collective memory of the crimes of communism in Sweden, this brief study has addressed the elusive question of location. This issue has to do with the way these recollections are accommodated in the much more comprehensive sphere of Swedish collective memory in general. Neither the palpable aspect of sites of memory, nor the more abstract one such as, for example, the political sphere exclusively could properly host these mediated recollections of communism. The level at which they are stored is bound to be the transnational one of the constellation of principles shared within the European cultural space as a whole.

Barash has argued that the function of collective memory is providing continuity and cohesion, once social, political and cultural continuity has been disrupted. ${ }^{46}$ The hiatus occasioned by communism in the history of Europe and the recollections of that period constitute an interruption whose account has to find its place in a wider narrative of Europe's history. The very effort of exploring the case of Sweden in connection with its memory of communism may well encourage further examination of the interplay between transnational remembrance and the dynamics of Europeanization.

46 J.A. Barash, Collective Memory..., p. 212. 


\section{BIBLIOGRAPHY}

Abrahamson K.A., Låt mig få städa klart! Om kommunister, kryptokommunister och antikommunister, Stockholm 2015.

Barash J.A., Collective Memory and the Historical Past, Chicago 2016.

Bergner P., Med historien som motståndare. SKP/VPK/V och det kommunistiska arvet 1956-2006, Stockholm 2013.

Berntson L., Nordin S., Efter revolutionen. Vänstern i svensk kulturdebatt sedan 1968, Stockholm 2017.

Blomqvist H., Ekdahl L. (eds.), Kommunismen - hot och löfte. Arbetarrörelsen i skuggan av Sovjetunionen 1917-1991, Stockholm 2002.

"Doc. 10765: Need for international condemnation of crimes of totalitarian communist regimes", Parliamentary Assembly, 16 December 2005, at <http://assembly.coe.int/nw/xml/XRef/ X2H-Xref-ViewHTML.asp?FileID=11097\&lang=EN >.

Eneberg K., Förnekelsens barn. Svenskarna som drog österut, Stockholm 2003.

Eneberg K., Tvingade till tystnad. En okänd historia om några svenska familjeöden, Stockholm 2000

Engman M. (ed.), Väst möter öst. Norden och Ryssland genom historien, Stockholm 1996.

Erll A., Memory in Culture, transl. by S.B. Young, Basingstoke 2011.

Frank E., "Nu granskar vi kommunismen”, Svenska Dagbladet, 2 September 2007.

Gerner K., Karlson K.-G. (eds.), Rysk spegel. Svenska berättelser om Sovjetunionen - och om Sverige, Lund 2008.

Jarausch K.H., "Nightmares or Daydreams? A Postscript on the Europeanisation of Memories”, in M. Pakier, B. Stråth (eds.), A European Memory? Contested Memories and the Politics of Remembrance, New York 2010.

Jarausch K.H., Linderberger T., "Contours of a Critical History of Contemporary Europe: A Transnational Agenda”, in K.H. Jarausch, T. Linderberger (eds.), Conflicted Memories. Europeanizing Contemporary Histories, New York 2011.

Judt T., Postwar. A History of Europe since 1945, London 2007.

Karlsson K.-G., Europeiska möten med historien. Historiekulturella perspektiv på andra världskriget, forintelsen och den kommunistisk a terrorn, Stockholm 2010.

Karlsson K.-G., “The Uses of History and the Third Wave of Europeanisation”, in M. Pakier, B. Stråth (eds.), A European Memory? Contested Memories and the Politics of Remembrance, New York 2010.

Kershaw I., Lewin M. (eds.), Stalinism and Nazism. Dictatorships in Comparison, Cambridge 1997.

“Kirunasvenskarna”, Forum för Levande Historia, 2013, at <http://www.levandehistoria.se/ fakta-fordjupning/kommunistiska-regimers-brott-mot-manskligheten/kirunasvenskarna $>$.

“Kirunasvenskarna - drömmen om Stalins Sovjet”, Sveriges Radio, 3 May 2015, at <http:// sverigesradio.se/sida/avsnitt/537025?programid=2519>.

“Kommunismens brott mot mänskligheten”, Svenska Dagbladet, 11 March 2008.

"Lars Ohly slutar kalla sig kommunist”, Sveriges Radio, 30 October 2005, at < http://sverigesradio. se/sida/artikel.aspx?programid $=83 \&$ artikel $=723787>$. 
Lars Oblys mörka föflutna, Sveriges Television, 16 August 2009, at < https://www.youtube.com/ watch?v=RbzRZWFZHs4>.

Liedman S.-E., "Ovetenskaplig efterskrift”, in L.-A. Norborg, S.-E. Liedman, U. Nymark, Lik i garderoben? En rapport om SKP/VPks internationella förbindelser, Stockholm 1992.

Lundell V., Det omstridda arvet. Den kommunistiska erfarenheten i dansk och svensk historiekultur, Lund 2017.

Margalit A., The Ethics of Memory, Cambridge, Mass. 2003.

Motion till riksdagen 2015/16:101 av Mia Sydow Mölleby m.fl. (V). Minnesmärke för Kirunasvenskarna, at <https://data.riksdagen.se/fil/4D125B74-6D00-481A-ACAD-2B3C1894DE50>.

“Om bokstavsvänstern”, Sveriges Radio, 24 September 2015, at <http://sverigesradio.se/sida/ avsnitt $/ 620692$ ? programid $=4747>$.

“Om oss", Forum för Levande Historia, at <http://www.levandehistoria.se/om-oss >

"Rebellerna”, Sveriges Radio, 28 June 2009, at <http://sverigesradio.se/sida/artikel.aspx?progr amid $=909$ \&artikel $=2895155>$.

"Resolution 1481 (2006): Need for international condemnation of crimes of totalitarian communist regimes", Parliamentary Assembly, 25 January 2006, at <http://assembly.coe.int/nw/xml/ XRef/Xref-XML2HTML-en.asp?fileid=17403\&lang=en $>$.

Rothstein B., "Forskaruppropet i DN saknar konsekvens", Svenska Dagbladet, 5 April 2008.

"Schyman: Jag har aldrig varit kommunist", Sveriges Radio, 17 August 2006, at <http:// sverigesradio.se/sida/artikel.aspx?programid $=1602$ \&artikel $=906656>$.

Stenfeldt J., Dystopiernas seger. Totalitarism som orienteringspunkt i efterkrigstidens svenska idédebatt, [Höör] 2013.

“Tungt vänsteravhopp i protest mot Ohly", Sveriges Radio, 14 October 2004, at <http:// sverigesradio.se/sida/artikel.aspx?programid=83\&artikel $=486827>$.

"Uppdrag och uppläggning”, in L.-A. Norborg, S.-E. Liedman, U. Nymark, Lik i garderoben? En rapport om SKP/VPks internationella forbindelser, Stockholm 1992.

"Upprop mot statlig kampanjhistoria”, Lista över samtliga undertecknare, at <http://www. historieuppropet.se >.

Velicu A., "The Return of World History and Transcultural Memory”, Buletin Ştiințific. Revistă de Etnografie, Ştiințele Naturii şi Muzeologie (Serie Noua), vol. 21, no. 34 (2014).

Whitling F., "Damnatio Memoriae and the Power of Remembrance: Reflections on Memory and History", in M. Pakier, B. Stråth (eds.), A European Memory? Contested Memories and the Politics of Remembrance, New York 2010.

Zander U., Fornstora dagar, moderna tider. Bruk av och debatter om svensk historia frän sekelskifte till sekelskifte, Lund 2001. 
Adrian VELICU, after university studies in Bucharest, Helsinki and Uppsala, completed a PhD in English Literature at Uppsala University (Unifying Strategies in Virginia Woolf's Experimental Fiction, Uppsala 1985). Between 1981-1992 he worked in London as a radio producer and journalist for the BBC World Service. Back in Sweden, a period of studies and part-time teaching in the history of ideas at Gothenburg University led to a PhD in the History of Ideas (Versions of Exile Morality. Refugees in Britain, 1790-1845, Göteborg 2001). His interest in the $18^{\text {th }}$ century resulted in several shorter studies and the monograph Civic Catechisms and Reason in the French Revolution (London 2010). At Karlstad University (2003-2015), apart from teaching and researching the history of ideas, he has been part of a research group working on collective memory. Among the resulting publications, one can mention European Cultural Memory Post-89 (ed. with Conny Mithander, John Sundholm, Amsterdam 2013). During 2018, Adrian Velicu is visiting researcher at the University of Copenhagen, Department of Cross-Cultural and Regional Studies. 